\title{
Effects of BLM on Students' Reading Proficiency: An Empirical Study among Vocational College Students Based on POA
}

\author{
Qinhua Ji \\ School of Humanities, Tiangong University, Tianjin, China \\ Email: qinhuaji2020@163.com
}

How to cite this paper: Ji, Q.H. (2022) Effects of BLM on Students' Reading Proficiency: An Empirical Study among Vocational College Students Based on POA. Open Access Library Journal, 9: e8368.

https://doi.org/10.4236/oalib.1108368

Received: January 13, 2022

Accepted: January 26, 2022

Published: January 29, 2022

Copyright () 2022 by author(s) and Open Access Library Inc.

This work is licensed under the Creative Commons Attribution International License (CC BY 4.0).

http://creativecommons.org/licenses/by/4.0/

\section{(c) (i) Open Access}

\begin{abstract}
The combination of face-to-face instruction with online learning claims the emergence of Blended Learning (BL). To solve the problem of "learning and using being separated", Professor Wen Qiufang put forward Production-Oriented Approach (POA). This paper discusses the effects of blended learning model of English reading among 65 vocational college students guided by POA. Questionnaire and interview are used as the research instruments. Data are analyzed by SPSS 22.0. The results indicated that blended learning model guided by POA can improve students' reading performance. And the effects of blended learning model differ in students of different English levels.
\end{abstract}

\section{Subject Areas}

English Language Teaching

\section{Keywords}

Blended Learning, Production-Oriented Approach, Vocational College Students, English Reading

\section{Introduction}

As Information Technology develops, education, especially in language teaching and learning, is greatly revolutionized. The combination of face-to-face instruction with online learning claims the emergence of Blended Learning (BL). To solve the problem of "learning and using being separated", the latest theoretical system with Chinese characteristics in language teaching-POA (Production-Oriented Approach), was formally put forward by Professor Wen Qiufang with her team 
in 2014 and upgraded in 2018. Vocational education, as a part of higher education, plays an increasingly crucial role in cultivating skilled talent. Due to the fact that students in vocational colleges greatly differ in English proficiency and motivations for learning English, it is extremely tough to satisfy each student's needs and conduct individualized teaching. Thus this paper aims to explore the effects of blended learning model of English reading among vocational colleges guided by POA. The results indicated that blended learning model guided by POA can improve students' reading performance. And the effects of blended learning model differ in students of different English levels. Furthermore, this paper can be divided into five parts. The first part is a brief introduction of research background. The second part displays literature review at home and abroad. And research methodology includes research questions, research subjects, research instruments and research procedures. Then data are collected and discussed in the next part. At last, a conclusion can be drawn.

\section{Literature Review}

\subsection{Blended Learning in Language Teaching Abroad}

“The term 'blended learning' first gained widespread currency in corporate training situations to describe the combination of teaching and learning approaches that included coaching, mentoring, online interactions, face-to-face classes, and on-job training" [1]. Research on definitions of blended learning can be classified into two types. One is to combine classroom teaching and online courses based on the percentage of online learning. In 2007, Smith and Kurthen distinguish related terms "web-enhanced", "blended learning", "hybrid learning" and "fully online learning" based on the percentages of online learning. They point out that blended learning refers to less than $45 \%$ of important online activities are used in face-to-face instruction [2]. And it is criticized for being oversimplified by only comparing time of online learning. In 2008, Watson presents that "blended learning defines a major segment of a continuum between fully online, at-a-distance courses, and fully face-to-face courses that use few or no Internet-based resources" [3]. And seven different categories of blended learning continuum are illustrated in detail.

The definition of blended learning also refers to blending face-to-face and online instruction, various pedagogical approaches and so on. In 2004, Garrison and Kanuka defines blended learning as "the thoughtful integration of classroom face-to-face learning experiences with online learning experiences" [4]. In 2006, Bonk and Graham advocates that "Blended learning systems combine face-to-face instruction with computer-mediated instruction" in The Handbook of Blended Learning Environments. Global Perspectives, Local Designs [5]. And different media and teaching methods differ in a continuum. Blended learning systems can be categorized in three ways: enabling approaches, enhancing approaches and transforming approaches. Besides, various models are raised to expatiate blended learning in which Community of Inquiry is the most influential one. 


\subsection{Blended Learning in English Teaching in China}

Compared with western scholars, domestic experts focus more on practical use of blended learning, such as influencing factors and effects than that on theoretical discussion. Next research on blended learning will be elaborated theoretically and practically.

In 2004, He Kekang, the first person who put forward blended learning after participating in The $7^{\text {th }}$ Global Chinese Conference of Computer in Education which marks the beginning of domestic research. He advocated that "blended learning aims to combine advantages of traditional teaching modes with that of E-learning (Digital Learning or Online Learning). Teachers should play a leading role in guiding, enlightening and monitoring in the whole teaching process while students, as main body of learning process, should fully reflect their initiative, enthusiasm and creativity" [6]. In 2004, Li Kedong and Zhao Jianhua illustrate blended learning "Principles and Application Models of Blended Learning". It refers to an organic integration of face-to-face teaching and online learning in order to reduce the cost and improve teaching efficiency [7]. The concept of blended learning presented by He Kekang is used in this research.

Blended learning has been put into teaching practice which can be categorized into four types: different platforms, blended learning models, different guiding theories and influential factors. For example, Ling Qian and Ma Wulin verify the effectiveness of blended learning in "Research on Blended Learning of College English Based on Web2.0 Platform" [8]. Cao Peisheng published "Research on the Construction and Effect of ESP Blended Learning Mode Based on Flipped Classroom". The study indicates that the blended ESP teaching mode in a flipped classroom can make courses more challenging, increase class participation, improve learning efficiency and practical ability [9].

\subsection{Blended Learning Model Based on POA in China}

In this part, blended learning models of English based on POA are discussed theoretically and practically.

Theoretically speaking, in 2021, Wang Lili and Zhang Xiaohui display specific methods and effective strategies of first-rate college course in "Construction of First-Class Blended College English Teaching with Production-Oriented Approach". It includes output-driven teaching objectives, theme-centered teaching contents, FC-based teaching methods, multiple assessment as well as construction of moral teachers [10].

Practically speaking, blended learning models are constructed and put into teaching practice. For example, in 2019, Li Zuo put forward a blended learning mode guided by POA in "A Study on Blended Learning Model of English SPOC in Vocational Colleges". And the results show that blended learning model integrates online and offline resources, which greatly makes the time and space of learning flexible and advances effective learning and language use [11]. 


\section{Research Methodology}

In this part, research questions, research subjects, research instruments and research procedures are presented respectively.

This thesis aims to explore the effects of blended learning model of English reading guided by POA among vocational college students. Three research questions are to be answered. What is the status quo of English reading for vocational college students? Can blended learning model improve students' English reading performance? If can, in what ways? To what extent are students of different English levels affected by blended learning model?

Two classes of Environment Art Design in Grade 2020 from Tianjin Light Industry Vocational Technical College are selected as research subjects. These two classes with 34 students in each class are taught by the author. And Class 1 is randomly chosen as controlled class (CC) while Class 2 is experimental class (EC). The traditionally computer-assisted teaching is applied to Class 1 while blended learning model guided by POA to Class 2 .

Questionnaire and interview are used as research instruments. To better understand status quo of vocational college students' English reading, questionnaire is divided into three parts: basic information; learners; teaching model.

Firstly, basic information covers gender, number, English score in China's Entrance Examination for College and duration of English learning.

Secondly, the part of learners includes learning belief, learning style and learning autonomy. Statements are selected carefully from Horwitz's Beliefs About Language Learning Inventory (BALLI), Reid's Perceptual Learning Style Preference Questionnaire and Xu Jinfen's questionnaire about learning autonomy respectively. And 35 statements are used in total. Questions 1 - 13 are concerned about students' learning belief. Questions 14 - 19 are related to students' learning styles. Besides, Questions 20 - 28 are about students' learning autonomy (See Appendix I).

To ensure that the questionnaire is valid and reliable, tests are conducted. Then the KMO and Bartlett's test shows that the validity coefficient is 0.767 (See Table 1) while reliability coefficient is 0.948 which indicates that the test is reliable (See Table 2). Hence the questionnaire is feasible.

Candidates are required to make choices according to the actual situation. And after a pilot study, modifications are made.

The outline of a semi-interview is as follows. Do you like blended learning model guided by POA? Does blended learning model used by teachers in the classroom improve your reading performance? Does blended learning model affect your learning belief in English? Does blended learning model change your learning style? Does blended learning model improve your autonomous learning ability? In what ways can teachers make improvements after this semester?

Due to COVID-19 pandemic, students were asked to have classes online for 
Table 1. Validity test of the questionnaire.

\begin{tabular}{lcc}
\hline \multicolumn{3}{c}{ KMO and Bartlett's Test } \\
\hline Kaiser-Meyer-Olkin Measure of Sampling Adequacy. & 0.767 \\
& Approx. Chi-Square & 2462.365 \\
Bartlett's Test of Sphericity & $\mathrm{df}$ & 595 \\
& Sig. & 0.000 \\
\hline
\end{tabular}

Table 2. Reliability test of the questionnaire.

\begin{tabular}{ccc}
\hline & Reliability Statistics & \\
\hline Cronbach's Alpha & $\begin{array}{c}\text { Cronbach's Alpha Based on } \\
\text { Standardized Items }\end{array}$ & N of Items \\
\hline 0.948 & 0.950 & 35 \\
\hline
\end{tabular}

the first two weeks. Hence experimental period lasted for 15 weeks from 15th March, 2021 to 27th June, 2021. The research procedures are composed of four steps: the distribution of the questionnaire, the administration of the pretest and post-test, conduction of the interview and statistical analysis of test data.

\section{Data Analysis and Discussion}

\subsection{The Status Quo of English Reading}

According to the collected questionnaires, basic information about gender, English scores in China's Entrance Examination for College and duration of English learning are analyzed. According to the data, nearly all students have learned English for about ten years except for two students from minority areas who never learn English. And their English scores in China's Entrance Examination for College range from 25 to 98 out of 150. Some of them didn't take the China's Entrance Examination for College in June. Hence it can be found that although they have learned English for quite a long time, their English proficiency is generally poor and significantly different.

Questions 1 - 28 relates to students' learning belief, learning style and learning autonomy respectively. In conclusion, students are not interested in English and weakly motivated to learn it. Although they have learned English for almost 10 years, their English proficiency is poor. Secondly, they prefer to listen to teachers' lectures and participate in class activities and group discussions. There are also some students who prefer to study alone. Thirdly, over half of the students can understand the teacher's requirement. Only one third of students make their own plans, monitor the use of strategies who have poor independent learning ability.

\subsection{Blended Learning Model and Students' Reading Performance}

\subsubsection{Results of Pretest Scores in CC and EC}

Before the teaching experiment, test papers are distributed to students of two 
classes in order to know their English levels and see if there is comparability between CC and EC. Data are put into SPSS 22.0 in which Independent Samples $t$-Test is conducted. The results are as following (Table 3).

It can be found that from Table 4 that students of EC were not significantly different from those of CC on pretest scores $(t(60)=-0.097, p=0.923>0.05)$. And the average score of students from CC is 57.06 which is a little lower than that of students from EC. The Mean of EC is 57.48 , which shows that the difference between the means is -0.42 on a 100 -point test.

Therefore, it can be seen that students' English reading proficiency is almost similar and a controlled experiment can be conducted between these two classes. In order to know the difference of pretest and post-test scores in CC and EC, test papers are distributed to students of two classes again after the teaching experiment.

\subsubsection{Results of Post-Test Scores in CC and EC}

After the teaching experiment, Post-test scores in CC and EC are to be compared. Data are also put into SPSS 22.0 in which Independent Samples $t$-Test is conducted. The results are as follows (Table 5).

It can be found that from Table 6 that students of EC were significantly different from those of CC on post-test score $(t(60)=-2.413, p=0.018<0.05)$. And the average score of students from CC is 61.94 which is much lower than that of students from EC. The Mean of EC is 71.42 which shows that the difference between the means is -9.48 on a 100 -point test. Therefore, it can be seen

Table 3. Group statistics of pretest scores in CC and EC.

\begin{tabular}{lccccc}
\hline \multicolumn{7}{c}{ Group Statistics } \\
& Class & N & Mean & $\begin{array}{c}\text { Std. } \\
\text { Deviation }\end{array}$ & $\begin{array}{c}\text { Std. Error } \\
\text { Mean }\end{array}$ \\
\hline \multirow{3}{*}{ Pretest Scores } & CC & 31 & 57.06 & 18.461 & 3.316 \\
& EC & 31 & 57.48 & 15.569 & 2.796 \\
\hline
\end{tabular}

Table 4. Independent sample $t$-test of pretest scores.

\begin{tabular}{|c|c|c|c|c|c|c|c|c|c|c|}
\hline \multicolumn{11}{|c|}{ Independent Samples Test } \\
\hline & & \multicolumn{2}{|c|}{$\begin{array}{l}\text { Levene's Test } \\
\text { for Equality } \\
\text { of Variances }\end{array}$} & \multicolumn{7}{|c|}{ t-test for Equality of Means } \\
\hline & & \multirow[t]{2}{*}{$\mathrm{F}$} & \multirow[t]{2}{*}{ Sig. } & \multirow[t]{2}{*}{$\mathrm{t}$} & \multirow[t]{2}{*}{$\mathrm{df}$} & \multirow[t]{2}{*}{$\begin{array}{c}\text { Sig. } \\
\text { (2-tailed) }\end{array}$} & \multirow[t]{2}{*}{$\begin{array}{c}\text { Mean } \\
\text { Difference }\end{array}$} & \multirow[t]{2}{*}{$\begin{array}{l}\text { Std. Error } \\
\text { Difference }\end{array}$} & \multicolumn{2}{|c|}{$\begin{array}{c}95 \% \\
\text { Confidence } \\
\text { Interval of the } \\
\text { Difference }\end{array}$} \\
\hline & & & & & & & & & Lower & Upper \\
\hline \multirow[b]{2}{*}{$\begin{array}{l}\text { Pretest } \\
\text { Scores }\end{array}$} & $\begin{array}{c}\text { Equal } \\
\text { variances } \\
\text { assumed }\end{array}$ & 0.382 & 0.539 & -0.097 & 60 & 0.923 & -0.419 & 4.337 & -9.095 & 8.257 \\
\hline & $\begin{array}{c}\text { Equal } \\
\text { variances } \\
\text { not } \\
\text { assumed }\end{array}$ & & & -0.097 & 58.339 & 0.923 & -0.419 & 4.337 & -9.100 & 8.262 \\
\hline
\end{tabular}


Table 5. Group statistics of post-test scores in CC and EC.

\begin{tabular}{cccccc}
\hline \multicolumn{5}{c}{ Group Statistics } \\
\hline & Class & $\mathrm{N}$ & Mean & $\begin{array}{c}\text { Std. } \\
\text { Deviation }\end{array}$ & $\begin{array}{c}\text { Std. Error } \\
\text { Mean }\end{array}$ \\
\hline $\begin{array}{c}\text { Post-test } \\
\text { Scores }\end{array}$ & CC & 31 & 61.94 & 18.325 & 3.291 \\
\hline
\end{tabular}

Table 6. Independent samples $t$-test of post-test scores.

\begin{tabular}{|c|c|c|c|c|c|c|c|c|c|c|}
\hline \multicolumn{11}{|c|}{ Independent Samples Test } \\
\hline & & \multicolumn{2}{|c|}{$\begin{array}{l}\text { Levene's test } \\
\text { for equality } \\
\text { of variances }\end{array}$} & \multicolumn{7}{|c|}{ t-test for Equality of Means } \\
\hline & & \multirow[t]{2}{*}{$\mathrm{F}$} & \multirow[t]{2}{*}{ Sig. } & \multirow[t]{2}{*}{$\mathrm{t}$} & \multirow[t]{2}{*}{$\mathrm{df}$} & \multirow{2}{*}{$\begin{array}{c}\text { Sig. } \\
\text { (2-tailed) }\end{array}$} & \multirow{2}{*}{$\begin{array}{c}\text { Mean } \\
\text { Difference }\end{array}$} & \multirow{2}{*}{$\begin{array}{c}\text { Std. } \\
\text { Error } \\
\text { Difference }\end{array}$} & \multicolumn{2}{|c|}{$\begin{array}{l}\text { 95\% Confidence } \\
\text { Interval of the } \\
\text { Difference }\end{array}$} \\
\hline & & & & & & & & & Lower & Upper \\
\hline \multirow[b]{2}{*}{$\begin{array}{l}\text { Post-test } \\
\text { Scores }\end{array}$} & $\begin{array}{c}\text { Equal } \\
\text { variances } \\
\text { assumed }\end{array}$ & 4.435 & 0.039 & -2.423 & 60 & 0.018 & -9.484 & 3.915 & -17.315 & -1.653 \\
\hline & $\begin{array}{c}\text { Equal } \\
\text { variances } \\
\text { not } \\
\text { assumed }\end{array}$ & & & -2.423 & 51.238 & 0.019 & -9.484 & 3.915 & -17.342 & -1.625 \\
\hline
\end{tabular}

that students' English reading scores are indeed improved, which proves that blended learning model guided by POA is effective.

\subsubsection{Comparison of Pretest and Post-Test Scores in CC}

Test papers of CC were collected and analyzed in order to check if there is any progress in traditional English class featuring multimedia and blackboard which is teacher-centered.

Table 7 shows a comparison of students' scores between pretest and post-test of CC. The average pretest score is 57.06 while the post-test point is 61.94 after reserving two decimals. Thus, the score in is increased by 4.88 .

Table 8 shows that the value of correlation is 0.891 and Sig $=0.000(<0.05)$. Pretest and post-test in the EC are highly correlated. Therefore, paired samples test can be used to analyze data of two comprehension tests in the CC.

According to Table 9, pretest score is significantly different from post-test score of students from CC $(t(30)=-3.164, p=0.004<0.05)$. And the average score of post-tests is significantly higher than that of pretest in CC. The difference between the means is 4.88 on a 100 -point test. Hence students in CC make headway to some extent this semester.

\subsubsection{Comparison of Pretest and Post-Test Scores in EC}

Test papers of EC were collected and analyzed so as to find if there is any progress after teaching practice of Blended learning model guided by POA.

Table 10 shows a comparison of students' scores between pretest and 
Table 7. Paired sample statistics of pretest and post-test score in CC.

\begin{tabular}{cccccc}
\hline \multicolumn{6}{c}{ Paired Samples Statistics } \\
\hline & Mean & N & Std. Deviation & Std. Error Mean \\
\hline \multirow{2}{*}{ Pair 1 } & CC Pretest Score & 57.0645 & 31 & 18.46065 & 3.31563 \\
& CC Post-test Score & 61.9355 & 31 & 18.32473 & 3.29122 \\
\hline
\end{tabular}

Table 8. Paired samples correlations between pretest and post-test score in CC.

\begin{tabular}{ccccc}
\hline \multicolumn{4}{c}{ Paired Samples Correlations } \\
\hline & N & Correlation & Sig. \\
\hline Pair 1 & $\begin{array}{c}\text { CC Pretest Score \& CC } \\
\text { Post-test Score }\end{array}$ & 31 & 0.891 & 0.000 \\
\hline
\end{tabular}

Table 9. Paired samples test of pretest and post-test score in CC.

\begin{tabular}{|c|c|c|c|c|c|c|c|c|c|}
\hline \multicolumn{10}{|c|}{ Paired Samples Test } \\
\hline & & \multicolumn{5}{|c|}{ Paired Differences } & \multirow{3}{*}{$\mathrm{t}$} & \multirow{3}{*}{ df } & \multirow{3}{*}{$\begin{array}{c}\text { Sig. } \\
\text { (2-tailed) }\end{array}$} \\
\hline & & \multirow{2}{*}{ Mean } & \multirow{2}{*}{$\begin{array}{c}\text { Std. } \\
\text { Deviation }\end{array}$} & \multirow{2}{*}{$\begin{array}{l}\text { Std. } \\
\text { Error } \\
\text { Mean }\end{array}$} & \multicolumn{2}{|c|}{$\begin{array}{l}95 \% \text { Confidence Interval } \\
\text { of the Difference }\end{array}$} & & & \\
\hline & & & & & Lower & Upper & & & \\
\hline $\begin{array}{c}\text { Pair } \\
1\end{array}$ & $\begin{array}{c}\text { CC Pretest } \\
\text { Score - CC } \\
\text { Post-test Score }\end{array}$ & -4.87097 & 8.57027 & 1.53927 & -8.01457 & -1.72737 & -3.164 & 30 & 0.004 \\
\hline
\end{tabular}

Table 10. Paired samples statistics pretest and post-test score in EC.

\begin{tabular}{cccccc}
\hline \multicolumn{5}{c}{ Paired Samples Statistics } \\
\hline & Mean & N & $\begin{array}{c}\text { Std. } \\
\text { Deviation }\end{array}$ & $\begin{array}{c}\text { Std. Error } \\
\text { Mean }\end{array}$ \\
\hline Pair & EC Pretest Score & 57.4839 & 31 & 15.56892 & 2.79626 \\
1 & EC Post-test Score & 71.4194 & 31 & 11.80332 & 2.11994 \\
\hline
\end{tabular}

post-test of EC. The average pretest score is 57.48 while the post-test point is 71.42 after reserving two decimals. Therefore, the score in EC is increased by 13.94.

It can be seen from Table 11 that the value of correlation is 0.652 and Sig = 0.000 (less than 0.05) which shows that there is a strong correlation between pretest and post-test in the EC. Hence data collected from two comprehension tests can be calculated by paired samples test.

According to Table 12 in the following, pretest score is significantly different from post-test score of students from $\mathrm{EC}(t(30)=-6.505, p=0.000<0.05)$. And the average score of post-tests is significantly higher than that of pretest in EC. The difference between the means is 13.94 on a 100 -point test.

\subsubsection{Comparison of Pretest and Post-Test Scores in CC and EC}

Figure 1 shows percentage of scales in CC and EC in pretest. It can be found 
Table 11. Paired samples correlations between pretest and post-test score in EC.

\begin{tabular}{lcccc}
\hline \multicolumn{4}{c}{ Paired Samples Correlations } \\
\hline & $\mathrm{N}$ & Correlation & Sig. \\
\hline Pair 1 & $\begin{array}{c}\text { EC Pretest Score \& EC } \\
\text { Post-test Score }\end{array}$ & 31 & 0.652 & 0.000 \\
\hline
\end{tabular}

Table 12. Paired samples test of pretest and post-test score in EC.

\begin{tabular}{|c|c|c|c|c|c|c|c|c|c|}
\hline \multicolumn{10}{|c|}{ Paired Samples Test } \\
\hline & & \multicolumn{5}{|c|}{ Paired Differences } & \multirow{3}{*}{$\mathrm{t}$} & \multirow{3}{*}{ df } & \multirow{3}{*}{$\begin{array}{c}\text { Sig. } \\
\text { (2-tailed) }\end{array}$} \\
\hline & & \multirow{2}{*}{ Mean } & \multirow{2}{*}{$\begin{array}{c}\text { Std. } \\
\text { Deviation }\end{array}$} & \multirow{2}{*}{$\begin{array}{l}\text { Std. } \\
\text { Error } \\
\text { Mean }\end{array}$} & \multicolumn{2}{|c|}{$\begin{array}{l}95 \% \text { Confidence Interval } \\
\text { of the Difference }\end{array}$} & & & \\
\hline & & & & & Lower & Upper & & & \\
\hline $\begin{array}{c}\text { Pair } \\
1\end{array}$ & $\begin{array}{c}\text { EC Pretest } \\
\text { Score - EC } \\
\text { Post-test Score }\end{array}$ & -13.93548 & 11.92738 & 2.14222 & -18.31048 & -9.56049 & -6.505 & 30 & 0.000 \\
\hline
\end{tabular}

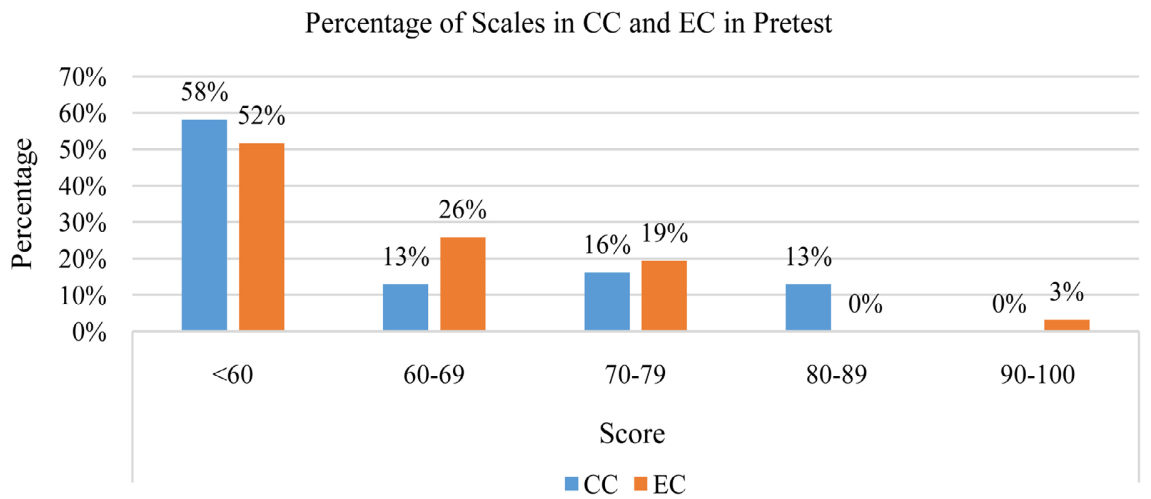

Figure 1. Percentage of scales in CC and EC in pretest.

that more than half of the students failed the pretest in both CC and EC (60 points are considered to pass the exam). In the range of $60-90$, the distribution of the CC is relatively uniform, while the EC is mainly concentrated in $60-79$. No one in EC scored 80 - 89. However, 3\% of the students scored $90-100$.

Figure 2 shows percentage of scales of CC and EC in post-test. It can be seen that students scored less than 60 in CC decreased by 13\% (58\% - 45\%) while students in EC decreased by $39 \%$ (52\% - 13\%) dramatically in post-test. It means after teaching experiment, almost all the students in EC can pass the test. Percentage of students in EC scored from 60 to 69 is the same in pretest and post-test while in CC the percentage rises by $3 \%(16 \%-13 \%)$ after the experiment. Percentage of the students scored from 70 to 79 in CC and EC increased in which the former one rise by $7 \%(23 \%-16 \%)$ while the latter one increased by $16 \%(35 \%-19 \%)$. As for students scored from 80 to 89 , the percentage in EC featuring $23 \%$ grows significantly faster than that in CC. In addition, the percentage of students scored from 90 to 100 barely changes in both CC and EC. 


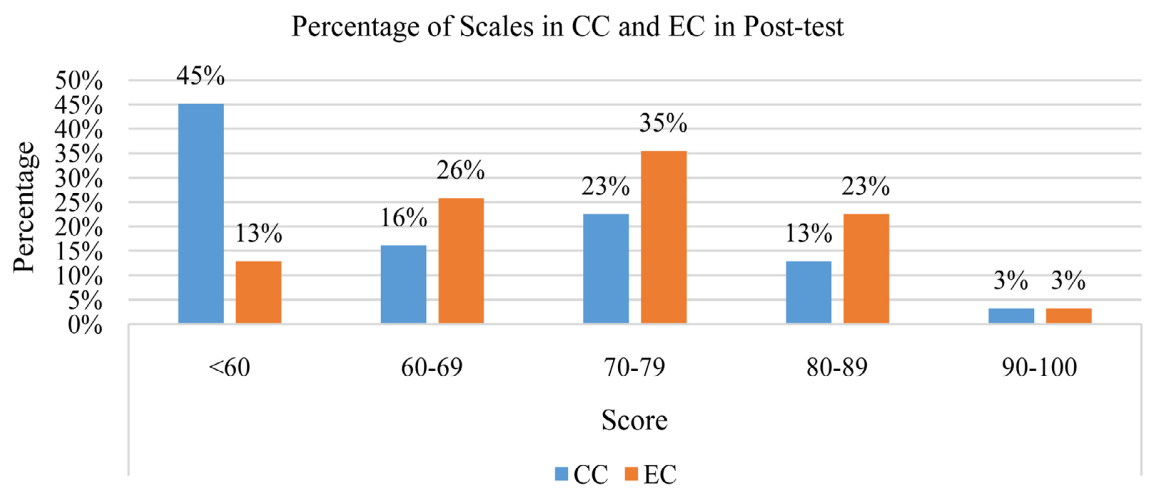

Figure 2. Percentage of scales in CC and EC in post-test.

In other words, after the teaching experiment, the number of students who failed the examin EC guided by blended learning model was greatly reduced and the number of those with relatively good grades increased. Whereas the number of excellent students remained unchanged on the whole. Generally speaking there was little change in CC.

\subsection{Effects of Blended Learning Model on Students' English Reading}

At the end of this experimental study, two students scored 0 - 60, 60 - 80 and 80 100 were respectively selected in EC for an interview. These students' grades are relatively stable although they make progress in reading performance. Students scored 0 - 60 are considered as low achievers, students scored 60 - 80 are intermediate achievers and students scored $80-100$ are regarded as high achievers. Then relevant records and analysis are made.

To sum up, all six students who participated in the interview unanimously expressed that the blended teaching model made the way of knowledge presentation more vivid and diversified. The class is more interesting, students' enthusiasm in exploration and learning is enhanced, and their independent learning ability is improved.

For English high achievers, there is barely change in test scores whether it is blended teaching model or not. Students indicated that blended teaching model focuses more on cooperative learning and less knowledge is learned in class. That is to say, students with high English proficiency are not greatly affected by teaching model. However, their learning enthusiasm and independent learning ability are improved to a certain extent.

For English intermediate achievers, their English scores are drastically improved after the implementation of blended teaching model. According to the interview, students said that they become more interested in English reading. And they are more impressed about knowledge through their own study. Moreover, they are conscious to make their own plans.

For English low achievers, their test scores are relatively improved. However, they dare to speak up and are increasingly willing to take part in classroom ac- 
tivities. Besides, they are very happy with their progress.

\section{Conclusion}

This paper has discussed the effects of blended learning model of English reading guided by POA among vocational college students. Three research questions have been solved. Generally speaking, vocational college students' English proficiency is poor. Most of them are not interested and weakly motivated in English learning. However, blended learning model guided by POA is beneficial to students' English learning after the experiment. For English high achievers, they are not greatly affected by different teaching models. For intermediate achievers, they make obvious progress. For low achievers, their test scores are relatively improved. But they dare to speak up and desire to participate in classroom activities. Besides, some suggestions are provided for teachers. In the "motivating" part, authenticity of scenarios needs to be focused on. And various productive objectives and teaching materials, diverse motivating designs for students with different English proficiency are of necessity. Self-valuation, peer evaluation and teacher evaluation need to be combined and personalized teaching should be carried out. There are some limitations: small and unrepresentative samples and limited teaching hours. Furthermore, how to better combine blended learning model and POA needs to be further discussed in the future.

\section{Conflicts of Interest}

The author declares no conflicts of interest.

\section{References}

[1] Hinkelman, D. (2018) Blended Technologies in Second Language Classrooms. 2nd Edition, Palgrave Macmillan, London. https://doi.org/10.1057/978-1-137-53686-0

[2] Glenn, G.S. and Kurthen, H. (2007) Front-Stage and Back-Stage in Hybrid E-Learning Face-to-Face Courses. International Journal on E-Learning, 6, 455-474.

[3] Watson, J. (2008) Blended Learning: The Convergence of Online and Face-to-Face Education. North American Council for Online Learning, Columbia.

[4] Garrison, D.R. and Kanuka, H. (2004) Blended Learning: Uncovering Its Transformative Potential in Higher Education. The Internet and Higher Education, 7, 95-105. https://doi.org/10.1016/j.iheduc.2004.02.001

[5] Bonk, C.J. and Charles, R.G. (2006) The Handbook of Blended Learning: Global Perspectives, Local Designs. John Wiley \& Sons, New Jersey.

[6] 何克抗. 从 Blended Learning 看教育技术理论的新发展(上) [J]. 电化教育研究, 2004(3): 1-6.

[7] 李克东, 赵建华. 混合学习的原理与应用模式[J]. 电化教育研究, 2004(7): 1-6.

[8] 凌茜, 马武林. 基于 Web 2.0 平台的大学英语混合式学习探究[J]. 电化教育研究, 2009(6): 107-108.

[9] 曹佩升. 基于翻转课堂的 ESP 课程混合式教学模式构建与效果研究[J]. 外语界, 2020(6): 87-94.

[10] 王丽丽, 张晓慧. 基于产出导向法的大学英语混合式 “一流课程”建设研究[J]. 黑 
龙江高教研究, 2019, 39(3): 146-151.

[11] 李佐. 高职大学英语 SPOC 混合式教学模式研究[J]. 中国职业技术教育, 2019(11): 76-80+86. 


\section{Appendix I}

\section{英语阅读学习现状问卷调查}

亲爱的同学们:

首先非常感谢大家的配合! 此调查问卷旨在了解学生英语阅读学习现状。本问卷仅用于本次教学实验的调查 研究, 不作他用, 请同学们如实填写, 谢谢大家!

\section{一. 基本信息}

性别

英语高考分数

英语学习年限

\section{二. 英语阅读学习现状}

下面是人们对学习英语的一些看法。这些看法无对错之分, 我们只对你的看法感兴趣, 请大家根据每个数字 所代表的含义选出其中一个数字填在句末的括号里, 所填的数字一定要能如实代表你自己的看法。

$1=$ “完全不符合”

$2=$ “基本不符合”

$3=$ “一般”

$4=$ “基本符合”

$5=$ “完全符合”

序号

问题

完全 基本

不符 不符一般

合合

1 英语是非常难学的语言。

2 我认为我能学好英语。

3 我认为我有学习英语的天赋。

4 我认为英语阅读的难点是句子理解。

5 我认为英语阅读的难点是单词。

6 我认为英语阅读的难点是概括大意或复述文章内容。

7 我认为英语阅读课的目的是学习单词和语法知识。

8 遇到看不懂的英文单词可以猜测其词义。

9 我认为多媒体教学资源能帮助我英语阅读。

10 学习英语是由于学校要求。

11 学好英语有利于我将来找份好工作。

12 学好英语后我就能更好的和英美人交往。

13 学好英语是因为我喜欢英语。

14 对我来说, 通过阅读来学习比听别人说要好。

15 听老师在课堂上讲课, 我会学得更好。

16 在课堂上, 通过动手做, 我会学得更好些。 


\section{Continued}

17 在课堂上参与学习任务或课堂活动时, 我会学到更多。

18 课堂上, 与其他人一起学习讨论时, 我的学习效率最高。

19 单独学习时, 我的学习效果会更好。

20 我能清楚地了解英语教师的教学目的和要求。

21 除老师布置的学习任务, 我能明确制定自己的学习计划。

22 我能根据自身的英语学习状况, 制定明确的学习目标。

23 我认为选择合理的学习策略非常重要。

24 在阅读练习中, 我能有意识地使用有效的阅读策略。

25 在英语阅读中, 我能有意识地评判自己的策略使用效果。

26 当发现自己的学习方法不切实际时, 我能及时换用更合适的学习方法。

27 我会在课前自己主动预习文章。

28 我能主动利用外语来进行原版小说、杂志以及相关材料的阅读。 